\title{
OPTIMASI BIAYA OPERASIONAL PADA KRL COMMUTER LINE DENGAN PEMBERANGKATAN KERETA
}

\section{Optimization of Operational Cost in KRL Commuter Line with Trainset Dispacthing}

\author{
Shelen Luciana ${ }^{1 *}$, Amril Aman ${ }^{2}$, Toni Bakhtiar ${ }^{3}$ \\ 1,2,3 Prodi Matematika, FMIPA, IPB University \\ Jl. Raya Dramaga, Bogor, 16680, Indonesia \\ e-mail:1*shelenluciana@gmail.com;2amril.aman@gmail.com; 3tbakhtiar@ipb.ac.id
}

Corresponding author*

\begin{abstract}
Abstrak
Pemberangkatan jumlah rangkaian kereta yang optimal dapat mengurangi penumpukan penumpang serta dapat mengoptimalkan biaya operasional. Penelitian ini bertujuan untuk membuat model pemberangkatan jumlah rangkaian kereta pada setiap slot waktu dengan biaya operasional minimum agar permintaan penumpang dapat terpenuhi. Dalam penelitian ini menggunakan parameter jumlah penumpang yang naik dan turun, ketersediaan setiap jenis rangkaian kereta, kapasitas kereta, biaya operasional dan batas waktu untuk menggunakan rangkaian kereta selama jam operasional. Model dibentuk ke dalam pemrograman linear integer dan diselesaikan dengan software Lingo 11.0. Model ini diterapkan pada satu arah jalur commuter line stasiun Bogor menuju Jakarta Kota. Pemberangkatan rangkaian kereta dilakukan dengan pemilihan jenis rangkaian $8 \mathrm{SF}, 10 \mathrm{SF}$ dan $12 \mathrm{SF}$ dengan biaya operasional minimum pada setiap slot waktu. Hasil optimum yang diperoleh selama jam opersional perlu memberangkatkan 56 perjalanan rangkaian kereta. Adanya keterbatasan studi dalam penelitian ini, diperoleh biaya operasional optimum pemberangkatan jumlah rangkaian kereta sebesar $302 C$.
\end{abstract}

Kata Kunci : Pemberangkatan rangkaian kereta, Commuter Line, Pemrograman Linear Integer

\begin{abstract}
Optimal trainset dispatching can reduce passenger build-up and optimize operational costs. This research aimed to create a model of trainset dispatching for each time slot with minimum operational costs so that passenger demand can be met. The parameters in this research are the number of passengers getting-on and getting-off, the availability of each type of train series, train capacity, operational costs, and time limits for using the training series during operational hours. The model was formed into integer linear programming and resolved with Lingo 11.0 software. This model is applied in one direction from Bogor station to the Jakarta Kota commuter line. Trainset dispatching is done by selecting the 8 SF, 10 SF, and 12 SF trainset types with minimum operational costs at each time slot. The optimum results obtained during operational hours need to dispatch 56 trainset trips. Due to the limitations of the study the optimum operational cost of trainset dispatched is obtained $302 C$.
\end{abstract}

Keywords: Trainset Dispatching, Commuter Line, Integer Linear Programming

Submitted: 10 December $2019 \quad$ Revised: 01 March $2020 \quad$ Accepted: 10 March 2020 


\section{PENDAHULUAN}

Sebagai ibu kota, Kota Jakarta merupakan kota pemicu munculnya komuter, yaitu seseorang yang berpergian ke suatu kota untuk bekerja dan kembali ke kota tempat tinggalnya setiap hari [5]. Jumlah komuter yang terus meningkat dan menyebabkan kepadatan penduduk akan memiliki pengaruh yang signifikan terhadap kemampuan transportasi dalam melayani kebutuhan mobilitas masyarakat. Menurut Peraturan Menteri Perhubungan No. 54 Tahun 2013 [7], arah pengembangan sistem transportasi di kawasan Jabodetabek ditekankan pada sistem pengembangan transportasi massal dan ramah lingkungan. Kompleksitas mobilisasi penduduk yang tinggal di perkotaan Indonesia seringkali tidak didukung oleh ketersediaan infrastruktur dan moda angkutan umum yang memadai [13]. Saat ini sarana transportasi umum yang cukup memadai untuk digunakan oleh masyarakat umum dalam jumlah besar yaitu KRL commuter line yang dikelola oleh PT. Kereta Commuter Indonesia (PT KCI) [1]. Berdasarkan data PT KCI jumlah penumpang KRL commuter line sepanjang tahun 2017 mencapai 315,8 juta penumpang dan naik 12,55\% dari tahun sebelumnya. Hal tersebut tentu akan berdampak pada ketersediaan rangkaian KRL commuter line untuk memenuhi permintaan penumpang. Dalam pelaksanaannya, KRL commuter line seringkali mengalami penumpukan penumpang terutama pada jam sibuk [6].

Salah satu solusi untuk meminimalkan penumpukan penumpang adalah dengan melakukan pemberangkatan sejumlah rangkaian kereta yang optimal terutama pada saat jam sibuk. Selain itu, pemberangkatan jumlah rangkaian kereta yang optimal dapat meminimumkan biaya operasional [11]. Biaya operasional tersebut terdiri atas biaya tetap dan tak tetap. Biaya tetap dialokasikan untuk perawatan mesin dan perawatan jalur rangkaian. Biaya tak tetap dialokasikan untuk penggunaan bahan bakar (listrik), pelayanan kebersihan, train crew [2]. Beberapa penelitian terkait pemberangkatan rangkaian kereta telah dilakukan oleh [3],[14],[8],[15],[4] yang secara umum memiliki fungsi tujuan meminimumkan biaya operasional melalui pemberangkatan sejumlah rangkaian kereta untuk memenuhi permintaan penumpang. Penelitian [15,4] memformulasikan model dalam bentuk Mixed Integer Linear Programming (MILP) dan [8] memformulasikan model dalam bentuk Mixed Integer Non Linear Programming (MINLP). Masalah pemberangkatan rangkaian kereta sangatlah kompleks terkait dengan ketersediaan infrastruktur [9].

Pada penelitian ini, masalah pemberangkatan rangkaian kereta pada KRL commuter line dilakukan dengan membuat formulasi model ke dalam bentuk Integer Linear Programming (ILP) dan diselesaikan dengan metode branch and bound dengan bantuan software Lingo 11.0. Metode branch and bound merupakan salah satu metode yang dapat menghasilkan penyelesaian optimal dari masalah ILP. Metode ini menghasilkan variabel-variabel keputusan berupa bilangan bulat. Konsep dasar branch dan bound merupakan teknik untuk membagi daerah fisibel menjadi cabang-cabang subproblem dan mengukurnya [12]. Tujuannya adalah melakukan pemilihan setiap jenis rangkaian kereta yang perlu diberangkatkan di stasiun awal pada setiap slot waktu agar permintaan penumpang dapat terpenuhi dengan biaya operasional yang minimum. Model akan dilakukan uji validitas dan diaplikasikan pada perjalanan satu arah yaitu stasiun Bogor menuju stasiun Jakarta Kota.

\section{METODE PENELITIAN}

Tujuan utama dari penelitian ini adalah membuat formulasi model untuk menentukan jumlah pemberangkatan rangkaian kereta pada KRL commuter line sehingga biaya operasional dapat optimum.

\subsection{Data}

Data pada penelitian ini menggunakan data sekunder yang diperoleh dari PT KCI. Data yang diperoleh merupakan data jumlah penumpang naik dan penumpang turun rata-rata per hari pada bulan Agustus 2019 yang dijadikan sebagai nilai parameter dari permintaan penumpang. Data jumlah ketersediaan rangkaian setiap Stand Formation (SF) atau jumlah gerbong dalam satu rangkaian pada bulan September 2019. Biaya operasional merupakan data yang tidak diakomodir oleh PT KCI. Oleh karena adanya keterbatasan informasi dari PT KCI terkait biaya operasional yang dikeluarkan setiap perjalanan SF maka biaya operasional pada penelitian ini dilambangkan dengan cost $C$ pada aplikasi formulasi model. 


\subsection{Tahapan Penelitian}

Tahapan-tahapan yang dilakukan dalam penelitian ini adalah sebagai berikut:

1. Memformulasikan model matematika untuk menentukan banyaknya pemberangkatan rangkaian kereta setiap periode slot waktu dengan tujuan meminimumkan biaya operasional ke dalam bentuk integer linear programming (ILP) dengan mengasumsikan kendala-kendala.

2. Melakukan uji validitas model untuk menentukan banyaknya pemberangkatan rangkaian kereta setiap slot waktu dengan menggunakan metode branch and bound dengan bantuan software Lingo 11.0.

3. Mengaplikasikan model matematika yang telah diuji validitas pada jalur KRL commuter line Bogor Jakarta Kota.

\subsection{Formulasi Masalah}

Penentuan banyaknya pemberangkatan rangkaian kereta selama jam operasional dipengaruhi oleh jumlah permintaan penumpang. Untuk membatasi permasalahan pada penelitian ini maka digunakan asumsiasumsi sebagai berikut:

1. Jenis rangkaian kereta yang digunakan homogen sehingga kapasitas gerbong dan kecepatan rangkaian kereta sama.

2. Tidak ada kereta dan jalur yang mengalami kerusakan.

3. Pemberangkatan rangkaian kereta pada KRL commuter line hanya satu arah stasiun Bogor menuju stasiun Jakarta Kota.

4. Setiap jenis rangkaian kereta yang dialokasikan dapat beroperasi lebih dari satu putaran dalam satu hari.

5. Headway antar kereta tidak ditentukan.

6. Demand penumpang di setiap stasiun terpenuhi.

Berdasarkan deskripsi masalah yang telah dipaparkan di atas, bentuk formulasi masalah dalam ILP adalah sebagai berikut:

i) Indeks

$\begin{array}{lll}i & : \text { stasiun; } & i=1,2,3, \ldots, N . \\ t & \text { : slot waktu; } & t=1,2,3, \ldots, T . \\ k & \text { : jenis rangkaian kereta SF 8, SF 10, SF 12; } & k=1,2,3 . \\ u & \text { : rangkaian kereta; } & u=1,2, \ldots, U .\end{array}$

ii) Himpunan

$\mathbb{K}_{1} \quad$ : himpunan rangkaian kereta jenis SF 8.

$\mathbb{K}_{2}$ : himpunan rangkaian kereta jenis SF 10.

$\mathbb{K}_{3}$ : himpunan rangkaian kereta jenis SF 12.

iii) Parameter

$P N_{t, i}$ : banyaknya penumpang yang naik di stasiun $i$ pada slot waktu $t$.

$P T_{t, i}$ : banyaknya penumpang yang turun di stasiun $i$ pada slot waktu $t$.

$\operatorname{Cap}_{k}$ : kapasitas setiap rangkaian kereta jenis $k$.

$C_{k} \quad$ : biaya operasional setiap perjalanan dari rangkaian kereta jenis $k$.

$G_{k} \quad$ : maksimal banyaknya periode waktu pemakaian jenis rangkaian kereta $k$ yang dapat dioperasikan selama jam operasional.

kmin : minimum banyaknya rangkaian kereta yang diberangkatkan di setiap slot waktu.

kmax : maksimum banyaknya rangkaian kereta yang diberangkatkan di setiap slot waktu.

iv) Variabel Keputusan

$N_{t}^{1} \quad$ : jumlah rangkaian kereta jenis SF 8 yang diberangkatkan pada slot waktu $t$.

$N_{t}^{2} \quad$ : jumlah rangkaian kereta jenis SF 10 yang diberangkatkan pada slot waktu $t$.

$N_{t}^{3} \quad$ : jumlah rangkaian kereta jenis SF 12 yang diberangkatkan pada slot waktu $t$.

$K_{u, t}^{1}:\left\{\begin{array}{l}1, \text { jika rangkaian kereta jenis SF } 8 \text { ke- } u \text { dioperasikan pada slot waktu } t \text {. } \\ 0, \text { selainnya. }\end{array}\right.$

$K_{u, t}^{2}:\left\{\begin{array}{l}1, \text { jika rangkaian kerete jenis SF } 10 \text { ke- } u \text { dioperasikan pada slot waktu } t . \\ 0, \text { selainnya. }\end{array}\right.$ 
$K_{u, t}^{3}:\left\{\begin{array}{l}1, \text { jika rangkaian kereta jenis SF } 12 \text { ke- } u \text { dioperasikan pada slot waktu } t . \\ 0, \text { selainnya. }\end{array}\right.$

v) Variabel Penjelas

$S_{t} \quad$ : total rangkaian kereta yang dioperasikan pada slot waktu $t$.

$K_{t}^{1} \quad$ : kapasitas total rangkaian kereta jenis 1 yang diberangkatkan pada slot waktu $t$.

$K_{t}^{2} \quad$ : kapasitas total rangkaian kereta jenis 2 yang diberangkatkan pada slot waktu $t$.

$K_{t}^{3} \quad$ : kapasitas total rangkaian kereta jenis 3 yang diberangkatkan pada slot waktu $t$.

$K T_{t} \quad$ : kapasitas total rangkaian kereta yang diberangkatkan pada slot waktu $t$.

$P K_{t, i}$ : banyaknya penumpang dalam kereta pada slot waktu $t$ di stasiun $i$.

$K B_{t, i}$ : kapasitas yang tersedia pada slot waktu $t$ di stasiun $i$ sebelum penumpang naik.

$K A_{t, i}$ : kapasitas yang tersedia pada slot waktu $t$ di stasiun $i$ setelah penumpang naik.

vi) Fungsi Objektif

Fungsi objektif dari model penelitian ini adalah meminimumkan total biaya operasional yang merupakan penjumlahan dari biaya perjalanan setiap jenis kereta dikalikan dengan jumlah pemberangkatan rangkaian kereta pada setiap slot waktu, yaitu:

$$
\min Z:=\sum_{t=1}^{T} c_{1} N_{t}^{1}+\sum_{t=1}^{T} c_{2} N_{t}^{2}+\sum_{t=1}^{T} c_{3} N_{t}^{3}, \forall t \in T .
$$

vii) Kendala-kendala

Kendala pada tahap menentukan pemberangkatan rangkaian kereta adalah sebagai berikut:

1. Total rangkaian kereta yang diberangkatkan pada slot waktu $t$ adalah penjumlahan dari setiap jenis rangkaian kereta jenis SF 8, SF 10, dan SF 12 yang dioperasikan pada slot waktu $t$ :

$$
S_{t}=N_{t}^{1}+N_{t}^{2}+N_{t}^{3}, \quad \forall t \in T .
$$

2. Kendala (3)-(4) berhubungan dengan total rangkaian kereta yang harus diberangkatkan pada slot waktu $t$, terdapat maksimum dan minimum rangkaian kereta yang perlu diberangkatkan:

$$
\begin{array}{ll}
S_{t} \geq k \min , & \forall t \in T . \\
S_{t} \leq k \max , & \forall t \in T .
\end{array}
$$

3. Kendala (5)-(7) berkaitan dengan junlah dari setiap jenis rangkaian kereta yang diberangkatkan pada waktu $t$ merupakan penjumlahan dari pemilihan setiap jenis rangkaian kereta yang diberangkatkan pada slot waktu $t$ :

$$
\begin{aligned}
& N_{t}^{1}=\sum_{u=1}^{\mathbb{K}_{1}} K_{u, t}^{1}, \quad \forall t \in T, \forall u \in \mathbb{K}_{1} . \\
& N_{t}^{2}=\sum_{u=1}^{\mathbb{K}_{2}} K_{u, t}^{2}, \quad \forall t \in T, \forall u \in \mathbb{K}_{2} . \\
& N_{t}^{3}=\sum_{u=1}^{\mathbb{K}_{3}} K_{u, t}^{3}, \quad \forall t \in T, \forall u \in \mathbb{K}_{3} .
\end{aligned}
$$

4. Kendala (8)-(10) berkaitan dengan pemilihan rangkaian kereta dari setiap jenis rangkaian kereta dimana setiap jenis rangkaian kereta memiliki batas slot waktu maksimal pengoperasian selama jam operasional:

$$
\begin{aligned}
& \sum_{t=1}^{T} K_{u, t}^{1} \leq G_{1}, \quad \forall t \in T, \forall u \in U . \\
& \sum_{t=1}^{T} K_{u, t}^{2} \leq G_{2}, \quad \forall t \in T, \forall u \in U .
\end{aligned}
$$




$$
\sum_{t=1}^{T} K_{u, t}^{3} \leq G_{3}, \forall t \in T, \forall u \in U .
$$

5. Kendala di bawah ini terkait dengan pemilihan setiap jenis rangkaian kereta dimana setiap jenis rangkaian kereta yang diberangkatkan pada slot waktu $t$ tidak digunakan dalam slot waktu berurutan:

$$
\begin{array}{ll}
K_{u, t}^{1}+K_{u, t+1}^{1}+K_{u, t+2}^{1} \leq 1, & \forall t \in T, \forall u \in \mathbb{K}_{1}, t \leq T-2 . \\
K_{u, t}^{2}+K_{u, t+1}^{2}+K_{u, t+2}^{2} \leq 1, & \forall t \in T, \forall u \in \mathbb{K}_{2}, t \leq T-2 . \\
K_{u, t}^{3}+K_{u, t+1}^{3}+K_{u, t+2}^{3} \leq 1, & \forall t \in T, \forall u \in \mathbb{K}_{3}, t \leq T-2 .
\end{array}
$$

6. Kendala di bawah ini berkaitan dengan jumlah penumpang di dalam kereta. Pada stasiun pertama, jumlah penumpang sama dengan penumpang yang naik (14). Sedangkan untuk stasiun berikutnya dipengaruhi oleh jumlah penumpang yang naik dan turun (15), yang dirumuskan

$$
\begin{gathered}
P K_{t, 1}=P N_{t, 1}, \quad \forall t \in T . \\
P K_{t, i+1}=P K_{t, i}+P N_{t, i+1}-P T_{t, i+1}, \quad \forall t \in T, \forall i \in N-1 .
\end{gathered}
$$

7. Kendala di bawah ini berkaitan dengan total kapasitas rangkaian kereta yang diberangkatkan pada slot waktu $t$ sama dengan perkalian antara kapasitas setiap jenis rangkaian kereta dan jumlah rangkaian kereta yang diberangkatkan pada slot waktu $t$ :

$$
\begin{array}{ll}
\operatorname{Cap}_{1} \times N_{t}^{1}=K_{t}^{1}, & \forall t \in T . \\
\operatorname{Cap}_{2} \times N_{t}^{2}=K_{t}^{2}, & \forall t \in T . \\
\operatorname{Cap}_{3} \times N_{t}^{2}=K_{t}^{3}, & \forall t \in T .
\end{array}
$$

Kapasitas total dari rangkaian kereta yang diberangkatkan adalah penjumlahan dari jumlah kapasitas setiap jenis rangkaian kereta yang diberangkatkan pada slot waktu $t$ :

$$
K_{t}^{1}+K_{t}^{2}+K_{t}^{3}=K T_{t}, \quad \forall t \in T .
$$

8. Kendala (20)-(23) berhubungan dengan kapasitas yang tersedia setelah naik dan turunnya penumpang di stasiun $i$ pada slot waktu $t$ :

- Jumlah kapsitas yang tersedia di stasiun pertama pada slot waktu $t$ sebelum penumpang naik sama dengan total kapasitas rangkaian kereta pada slot waktu $t$ :

$$
K B_{t, 1}=K T_{t}, \quad \forall t \in T .
$$

Kami juga memiliki batasan bersyarat berikut untuk $i=1$ pada slot waktu $t$, yaitu

$$
K B_{t, 1} \geq P N_{t, i}, \quad \forall t \in T, \forall i \in N .
$$

- Untuk stasiun berikutnya, jumlah kapasitas tersedia dipengaruhi oleh kapasitas total kereta dan jumlah penumpang di dalam kereta serta jumlah penumpang yang turun:

$$
K B_{t, i+1}=K T_{t}-P K_{t, i}+P T_{t, i+1}, \quad \forall t \in T, \forall i \in N-1 .
$$

- Jumlah kapasitas yang tersedia setelah penumpang naik dan turun pada slot waktu $t$ di stasiun $i$ sama dengan selisih antara kapasitas yang tersedia sebelum penumpang dan jumlah penumpang yang naik:

$$
K A_{t, i}=K B_{t, i}-P N_{t, i}, \quad \forall t \in T, \forall i \in N .
$$

9. Kendala bilangan integer, yaitu $N_{t}^{1}, N_{t}^{2}, N_{t}^{3} \in \mathbb{Z}, \forall t \in T$.

10.Kendala ketaknegatifan, yaitu $N_{t}^{1}, N_{t}^{2}, N_{t}^{3} \geq 0, \forall t \in T$.

11.Kendala bilangan biner, yaitu $K_{u, t}^{1}, K_{u, t}^{2}, K_{u, t}^{3} \in\{0,1\}, \forall t \in T, \forall u \in U$. 


\section{HASIL DAN PEMBAHASAN}

Formulasi model pemberangkatan rangkaian kereta akan dilakukan uji validitas dengan menggunakan beberapa skenario uji dalam simulasinya dan diselesaikan dengan bantuan software Lingo 11.0. Simulasi dilakukan untuk melihat sebuah eksperimen terhadap model yang dibentuk dengan tujuan memahami hasil output dari model tersebut [10].

\subsection{Pengujian Model}

Diberikan data 7 stasiun dan 10 slot waktu di mana setiap slot waktu merupakan periode waktu dari pembagian jam operasional seperti yang disajikan pada Tabel 1 .

Tabel 1. Penentuan slot waktu

\begin{tabular}{|cccc|}
\hline Slot waktu & Periode waktu & Slot waktu & Periode waktu \\
\hline 1 & $07.00-08.00$ & 6 & $12.00-13.00$ \\
2 & $08.00-09.00$ & 7 & $13.00-14.00$ \\
3 & $09.00-10.00$ & 8 & $14.00-15.00$ \\
4 & $10.00-11.00$ & 9 & $15.00-16.00$ \\
5 & $11.00-12.00$ & 10 & $16.00-17.00$ \\
\hline
\end{tabular}

Ada tiga skenario yang dilakukan untuk menguji validitas model. Nilai parameter yang digunakan dalam pengujian model ini yaitu kapasitas satu gerbong 30 sehingga kapasitas rangkaian SF 8, SF 10 dan SF 12 masing-masing yaitu $\operatorname{Cap}_{1}=240, \mathrm{Cap}_{2}=300$, dan $\operatorname{Cap}_{3}=360$. Setiap slot waktu, minimum rangkaian kereta yang diberangkatkan adalah 2 rangkaian kereta dan maksimum 9 rangkaian kereta. Dalam simulasi pengujian model, biaya operasional yang dikeluarkan untuk setiap perjalanan dari jenis SF merupakan asumsi dengan satuan rupiah.

\section{a. Skenario 1}

Pada skenario 1 diberikan data ketersediaan rangkaian kereta untuk setiap jenis rangkaian kereta, biaya operasional serta batas maksimum slot waktu penggunaan kereta selama jam operasional diberikan pada Tabel 2.

Tabel 2. Data skenario 1

\begin{tabular}{|ccccccccc|}
\hline \multicolumn{2}{|c|}{ Ketersediaan rangkaian kereta } & \multicolumn{3}{c|}{ Biaya operasional (Rp) } & \multicolumn{3}{c|}{ Batas maksimum (slot waktu) } \\
\hline SF 8 & SF 10 & SF 12 & SF 8 & SF 10 & SF 12 & SF 8 & SF 10 & SF 12 \\
\hline 0 & 7 & 3 & 0 & 3000 & 5000 & 0 & 4 & 3 \\
\hline
\end{tabular}

Berdasarkan data yang diberikan pada Tabel 2, diperoleh biaya operasional optimum yang dikeluarkan selama jam operasional sebesar Rp73.000,00 dan pengalokasian setiap jenis rangkaian kereta dapat dilihat pada Tabel 3 berikut.

Tabel 3. Hasil output alokasi pemberangkatan commuter line skenario 1

\begin{tabular}{|c|c|c|c|c|c|c|c|c|c|c|c|}
\hline \multirow{2}{*}{ Jenis rangkaian } & \multirow{2}{*}{ Rangkaian kereta ke- } & \multicolumn{10}{|c|}{ Slot waktu ke- } \\
\hline & & 1 & 2 & 3 & 4 & 5 & 6 & 7 & 8 & 9 & 10 \\
\hline & $\begin{array}{l}1 \\
2\end{array}$ & & & & & & & & & & \\
\hline & $\begin{array}{l}2 \\
3\end{array}$ & & & & & & & & & & \\
\hline SF 10 & 4 & & & & & & & & & & \\
\hline & 5 & & & & & & & & & & \\
\hline & 6 & & & & & & & & & & \\
\hline & 7 & & & & & & & & & & \\
\hline & 1 & & & & & & & & & & \\
\hline SF 12 & 2 & & & & & & & & & & \\
\hline & 3 & & & & & & & & & & \\
\hline
\end{tabular}

Hasil komputasi menunjukkan rangkaian kereta jenis SF 10 lebih banyak dibandingkan SF 12 yaitu rangkaian SF 10 sebanyak 21 perjalanan dan jenis SF 12 sebanyak 2 perjalanan selama jam operasional. 
Rangkaian kereta ke-3 jenis SF 12 tidak dioperasikan selama jam operasional. Jumlah pemberangkatan rangkaian kereta merupakan jenis rangkaian kereta dengan biaya operasional yang minimum.

\section{b. Skenario 2}

Pada skenario 2 diberikan data ketersediaan rangkaian kereta untuk setiap jenis rangkaian kereta, biaya operasional serta batas maksimum slot waktu penggunaan kereta selama jam operasional diberikan pada Tabel 4.

Tabel 4. Data skenario 2

\begin{tabular}{|ccccccccc|}
\hline \multicolumn{2}{|c|}{ Ketersediaan rangkaian kereta } & \multicolumn{4}{c|}{ Biaya operasional (Rp) } & \multicolumn{3}{c|}{ Batas maksimum (slot waktu) } \\
\hline SF 8 & SF 10 & SF 12 & SF 8 & SF 10 & SF 12 & SF 8 & SF 10 & SF 12 \\
\hline 7 & 3 & 0 & 9000 & 5000 & 0 & 5 & 2 & 0 \\
\hline
\end{tabular}

Berdasarkan data yang diberikan pada Tabel 4, diperoleh biaya operasional optimum yang dikeluarkan selama jam operasional sebesar Rp143.000,00 dan pengalokasian setiap jenis rangkaian kereta dapat dilihat pada Tabel 5 berikut.

Tabel 5. Hasil output alokasi pemberangkatan commuter line skenario 2

\begin{tabular}{|c|c|c|c|c|c|c|c|c|c|c|c|}
\hline \multirow{2}{*}{ Jenis rangkaian } & \multirow{2}{*}{$\begin{array}{c}\text { Rangkaian kereta } \\
\text { ke- }\end{array}$} & \multicolumn{10}{|c|}{ Slot waktu ke- } \\
\hline & & 1 & 2 & 3 & 4 & 5 & 6 & 7 & 8 & 9 & 10 \\
\hline & 1 & & & & & & & & & & \\
\hline & 2 & & & & & & & & & & \\
\hline & 3 & & & & & & & & & & \\
\hline SF 8 & 4 & & & & & & & & & & \\
\hline & 5 & & & & & & & & & & \\
\hline & 6 & & & & & & & & & & \\
\hline & 7 & & & & & & & & & & \\
\hline & 1 & & & & & & & & & & \\
\hline SF 10 & 2 & & & & & & & & & & \\
\hline & 3 & & & & & & & & & & \\
\hline
\end{tabular}

Hasil komputasi menunjukkan bahwa pemberangkatan rangkaian kereta untuk memenuhi permintaan penumpang jenis SF 8 sebanyak 18 perjalanan dan jenis SF 10 sebanyak 6 perjalanan selama jam operasional. Rangkaian kereta jenis SF 10 digunakan secara maksimal selama jam operasional dikarenakan biaya operasionalnya yang minimum. Kapasitas muatan yang lebih sedikit membuat rangkaian kereta jenis SF 8 diperlukan perjalanan yang lebih banyak agar permintaan penumpang dapat terpenuhi.

\section{c. Skenario 3}

Pada skenario 3 diberikan data ketersediaan rangkaian kereta untuk setiap jenis rangkaian kereta, biaya operasional serta batas maksimum slot waktu penggunaan kereta selama jam operasional diberikan pada Tabel 6.

Tabel 6. Data skenario 3

\begin{tabular}{|ccccccccc|}
\hline \multicolumn{2}{|c|}{ Ketersediaan rangkaian kereta } & \multicolumn{4}{c|}{ Biaya operasional (Rp) } & \multicolumn{4}{c|}{ Batas maksimum (slot waktu) } \\
\hline SF 8 & SF 10 & SF 12 & SF 8 & SF 10 & SF 12 & SF 8 & SF 10 & SF 12 \\
\hline 1 & 2 & 7 & 2000 & 3000 & 9000 & 3 & 2 & 4 \\
\hline
\end{tabular}

Berdasarkan data yang diberikan pada Tabel 6, diperoleh biaya operasional optimum yang dikeluarkan selama jam operasional sebesar Rp162.000,00 dan pengalokasian setiap jenis rangkaian kereta dapat dilihat pada Tabel 7 berikut. 
Tabel 7. Hasil output alokasi pemberangkatan commuter line skenario 3

\begin{tabular}{|c|c|c|c|c|c|c|c|c|c|c|c|}
\hline \multirow{2}{*}{ Jenis rangkaian } & \multirow{2}{*}{$\begin{array}{l}\text { Rangkaian } \\
\text { kereta ke- }\end{array}$} & \multicolumn{10}{|c|}{ Slot waktu ke- } \\
\hline & & 1 & 2 & 3 & 4 & 5 & 6 & 7 & 8 & 9 & 10 \\
\hline SF 8 & 1 & & & & & & & & & & \\
\hline SE 10 & 1 & & & & & & & & & & \\
\hline SF 10 & 2 & & & & & & & & & & \\
\hline & 1 & & & & & & & & & & \\
\hline & 2 & & & & & & & & & & \\
\hline & 3 & & & & & & & & & & \\
\hline SF 12 & 4 & & & & & & & & & & \\
\hline & 5 & & & & & & & & & & \\
\hline & 6 & & & & & & & & & & \\
\hline & 7 & & & & & & & & & & \\
\hline
\end{tabular}

Hasil komputasi menunjukkan bahwa pemberangkatan rangkaian kereta jenis SF 8 sebanyak 3 perjalanan, jenis SF 10 sebanyak 4 perjalanan dan jenis SF 12 sebanyak 16 perjalanan selama jam operasional. Rangkaian kereta jenis SF 8 dan SF 10 dioperasikan secara maksimal selama jam operasional dikarenakan memiliki biaya operasionalnya yang minimum. Meskipun rangkaian kereta jenis SF 12 memiliki biaya operasional yang tinggi, rangkaian kereta jenis SF 12 memiliki jumlah perjalanan lebih banyak untuk memenuhi permintaan penumpang.

\subsection{Aplikasi Model pada KRL Commuter Line Jalur Bogor - Jakarta Kota}

KRL commuter line adalah satu-satunya transportasi massal di Jabodetabek yang dapat mengangkut penumpang hingga 1.800 penumpang dalam sekali perjalanan. PT KCI mengelola 6 rute yang terdiri dari lebih dari 72 stasiun. Panjang lintasan KRL commuter line mencapai hingga 418 kilometer dan dilayani oleh lebih dari 1.060 unit kereta untuk melayani penumpang setiap harinya. Pada tahun 2019, KRL commuter line melayani lebih dari satu juta penumpang. Untuk mengurangi kompleksitas yang tidak dipertimbangan dalam penelitian ini, maka model hanya diterapkan pada jalur satu arah dari stasiun Bogor menuju stasiun Jakarta Kota yang melewati 24 stasiun dan jam operasional pukul 04.00 WIB hingga pukul 22.00 WIB. Selama jam operasional, kami membatasi waktu operasional yang terdiri dari 18 slot waktu dimana setiap slot waktu berselang satu jam. Slot waktu kemudian dibagi menjadi tiga kategori waktu yaitu, waktu sibuk terdiri dari slot waktu ke-1 hingga ke-4, waktu senggang terdiri dari slot waktu ke-5 hingga ke-12, dan waktu sepi terdiri dari slot waktu ke-13 hingga ke-18.

PT KCI memiliki tiga jenis rangkaian kereta yaitu SF 8 memiliki kapasitas 1.200 penumpang, SF 10 memiliki kapasitas 1.500 penumpang, dan SF 12 memiliki kapasitas 1.800 penumpang. Jumlah ketersediaan setiap jenis rangkaian kereta yaitu SF 8 terdiri dari 4 rangkaian kereta, SF 10 terdiri dari 9 rangkaian kereta, dan SF 12 terdiri dari 12 rangkaian kereta. Jumlah rata-rata penumpang naik dan turun di setiap stasiun disajikan pada Tabel 8 .

Tabel 8. Data rata-rata jumlah penumpang naik dan turun per hari setiap stasiun

\begin{tabular}{|clcc|}
\hline No. & Stasiun & Naik (orang) & Turun (orang) \\
\hline 1 & Bogor & 22196 & 0 \\
2 & Cilebut & 8357 & 594 \\
3 & Bojong Gede & 14775 & 1282 \\
4 & Citayam & 14499 & 1311 \\
5 & Depok & 10120 & 1433 \\
6 & Depok Baru & 10509 & 3625 \\
7 & Pondok Cina & 6703 & 3219 \\
8 & Univ. Indonesia & 3756 & 1015 \\
9 & Univ. Pancasila & 2156 & 1371 \\
10 & Lenteng Agung & 3363 & 1970 \\
11 & Tanjung Barat & 2397 & 3715 \\
12 & Pasar Minggu & 3249 & 5377 \\
13 & Pasar Minggu Baru & 677 & 1417 \\
14 & Duren Kalibata & 2310 & 6741 \\
15 & Cawang & 900 & 6144 \\
16 & Tebet & 1231 & 13455 \\
17 & Manggarai & 672 & 6519 \\
18 & Cikini & 443 & 7879 \\
& & &
\end{tabular}




\begin{tabular}{|llrr|}
19 & Gondangdia & 454 & 12058 \\
20 & Juanda & 376 & 8706 \\
21 & Sawah Besar & 120 & 4367 \\
22 & Mangga Besar & 111 & 3872 \\
23 & Jayakarta & 44 & 3114 \\
24 & Jakarta Kota & 0 & 10236 \\
\hline & Total & 109418 & 109418 \\
\hline
\end{tabular}

Dalam penelitian ini, kami mendistribusikan penumpang naik ke dalam slot waktu dengan ketentuan sebagai berikut, $45 \%$ dari total penumpang naik untuk waktu jam sibuk, $40 \%$ dari total penumpang naik untuk waktu senggang, dan $15 \%$ dari total penumpang naik untuk waktu sepi. Kemudian kami mendistribusikan penumpang yang turun ke dalam slot waktu berdasarkan urutan stasiun yang menurunkan penumpang lebih banyak dengan ketentuan 50\% dari total penumpang yang naik pada setiap slot waktu untuk stasiun Tebet, Gondangdia, Kota Jakarta, Juanda, Cikini, Duren Kalibata, Manggarai dan Cawang, 40\% dari total penumpang yang naik pada setiap slot waktu untuk stasiun Pasar Minggu, Sawah Besar, Mangga Besar, Tanjung Barat, Depok Baru, Pondok Cina dan Jayakarta, 10\% dari total penumpang yang naik pada setiap slot waktu untuk stasiun Lenteng Agung, Depok, Pasar Minggu Baru, Univ. Pancasila, Citayam, Bojong Gede, Univ. Indonesia, dan Cilebut. Terdapat batasan penggunaan setiap jenis rangkaian kereta selama jam operasional dikarenakan rangkaian kereta digunakan pula untuk arus sebaliknya. Jenis rangkaian kereta SF 8, SF 10 dan SF 12 masing-masing memiliki batas maksimal penggunaan rangkaian yaitu 2 slot waktu, 2 slot waktu, dan 6 slot waktu selama jam operasional.

Setiap slot waktu, minimum jumlah rangkaian kereta yang harus diberangkatkan adalah sebanyak 2 rangkaian kereta dan maksimum 5 rangkaian kereta. Berdasarkan data dan formulasi model melalui proses komputasi dengan software Lingo 11.0. diperoleh rangkaian kereta dispatching pada KRL commuter line setiap slot waktu pada Tabel 9.

Tabel 9. Jumlah pemberangkatan rangkaian kereta pada KRL commuter line

\begin{tabular}{|c|c|c|c|c|c|c|c|c|c|}
\hline \multirow{3}{*}{ Slot waktu } & \multirow{3}{*}{ Periode waktu } & \multirow{2}{*}{\multicolumn{3}{|c|}{$\begin{array}{c}\begin{array}{c}\text { Trainset dispatching } \\
\text { (rangkaian kereta) }\end{array} \\
\text { PT KCI }\end{array}$}} & \multirow{3}{*}{ Total } & \multirow{2}{*}{\multicolumn{3}{|c|}{$\begin{array}{c}\begin{array}{c}\text { Trainset dispatching } \\
\text { (rangkaian kereta) }\end{array} \\
\text { OR/MS }\end{array}$}} & \multirow{3}{*}{ Total } \\
\hline & & & & & & & & & \\
\hline & & SF 8 & SF 10 & SF 12 & & SF 8 & SF 10 & SF 12 & \\
\hline 1 & $04.00-05.00$ & 0 & 2 & 3 & 5 & 0 & 1 & 4 & 5 \\
\hline 2 & $05.00-06.00$ & 0 & 1 & 3 & 4 & 1 & 0 & 4 & 5 \\
\hline 3 & $06.00-07.00$ & 2 & 0 & 2 & 4 & 0 & 1 & 4 & 5 \\
\hline 4 & $07.00-08.00$ & 0 & 1 & 3 & 4 & 0 & 1 & 4 & 5 \\
\hline 5 & $08.00-09.00$ & 1 & 2 & 2 & 5 & 1 & 0 & 2 & 3 \\
\hline 6 & $09.00-10.00$ & 0 & 0 & 4 & 4 & 1 & 2 & 0 & 3 \\
\hline 7 & $10.00-11.00$ & 0 & 1 & 3 & 4 & 0 & 2 & 1 & 3 \\
\hline 8 & $11.00-12.00$ & 0 & 1 & 2 & 3 & 0 & 2 & 1 & 3 \\
\hline 9 & $12.00-13.00$ & 1 & 0 & 3 & 4 & 0 & 0 & 3 & 3 \\
\hline 10 & $13.00-14.00$ & 0 & 0 & 2 & 2 & 0 & 1 & 2 & 3 \\
\hline 11 & $14.00-15.00$ & 0 & 1 & 2 & 3 & 0 & 3 & 0 & 3 \\
\hline 12 & $15.00-16.00$ & 1 & 0 & 2 & 3 & 0 & 2 & 1 & 3 \\
\hline 13 & $16.00-17.00$ & 0 & 0 & 3 & 3 & 0 & 0 & 2 & 2 \\
\hline 14 & $17.00-18.00$ & 0 & 2 & 2 & 4 & 0 & 0 & 2 & 2 \\
\hline 15 & $18.00-19.00$ & 1 & 1 & 3 & 5 & 2 & 0 & 0 & 2 \\
\hline 16 & $19.00-20.00$ & 1 & 1 & 2 & 4 & 1 & 1 & 0 & 2 \\
\hline 17 & $20.00-21.00$ & 0 & 2 & 1 & 3 & 0 & 2 & 0 & 2 \\
\hline 18 & $21.00-22.00$ & 0 & 1 & 1 & 2 & 2 & 0 & 0 & 2 \\
\hline & Total & 7 & 16 & 43 & 66 & 8 & 18 & 30 & 56 \\
\hline
\end{tabular}

Melalui proses komputasi diperoleh pemberangkatan rangkaian kereta untuk waktu sibuk sebanyak 20 perjalanan rangkaian kereta, waktu senggang sebanyak 24 perjalanan rangkaian kereta dan waktu sepi 12 perjalanan rangkaian kereta. Total perjalanan yang diperoleh melalui operation research/management sains (OR/MS) yaitu 10 perjalanan lebih sedikit dibandingkan dengan kondisi existing untuk arah Bogor menuju Jakarta Kota, perbedaan total pemberangkatan rangkaian kereta dengan PT KCI disebabkan adanya arus balik Jakarta Kota - Bogor. Hal ini dapat disebabkan PT KCI mengantisipasi adanya lonjakan penumpang rute stasiun Jakarta Kota menuju stasiun Bogor pada saat pulang kerja (waktu sibuk). Sementara itu penelitian ini hanya mempertimbangkan rute Bogor - Jakarta Kota dalam analisis. 
Biaya operasional setiap jenis rangkaian kereta pada aplikasi model merupakan perbandingan berdasarkan jumlah gerbong dari setiap jenis rangkaian rangkaian kereta. Perbandingannya yaitu SF 8:SF 10:SF 12 sehingga diperoleh perbandingan 4:5:6 untuk masing-masing SF 8, SF 10, dan SF 12 yang dapat dilihat pada Tabel 10.

Tabel 10. Biaya operasional trainset dispatching KRL commuter line

\begin{tabular}{|cccc|}
\hline Jenis rangkaian & Biaya operasional & $\begin{array}{c}\text { Trainset dispatching } \\
\text { (perjalanan) }\end{array}$ & Total biaya operasional \\
\hline SF 8 & $4 C$ & 8 & $32 C$ \\
SF 10 & $5 C$ & 18 & $90 C$ \\
SF 12 & $6 C$ & 30 & $180 C$ \\
\hline & Total & 56 & $302 C$ \\
\hline
\end{tabular}

Dengan mengalikan jumlah rangkaian kereta yang diberangkatkan untuk setiap jenis rangkaian kereta pada setiap slot waktu dan biaya operasional setiap jenis rangkaian kereta sesuai dengan (1) diperoleh bahwa total biaya operasional optimum adalah $302 C$, dimana nilai $C$ nantinya dapat disesuaikan dengan biaya operasional aktual yang dikeluarkan oleh PT KCI.

\section{KESIMPULAN}

Masalah pemberangkatan jumlah rangkaian kereta pada KRL commuter line dapat dimodelkan dalam bentuk integer linear programming dan diselesaikan dengan metode branch and bound sehingga diperoleh pemberangkatan rangkaian kereta yang optimal dengan biaya operasional minimum untuk memenuhi permintaan penumpang. Biaya operasional minimum yang diperoleh berdasarkan OR/MS yaitu sebesar $302 C$. PT KCI memberangkatkan rangkaian kereta lebih sedikit pada saat waktu sibuk dibandingkan dengan hasil OR/MS. Dengan segala kompleksitas yang tidak diperhitungkan dalam penelitian ini, keputusan PT KCI memberangkatkan 66 perjalanan rangkaian kereta per hari untuk rute stasiun Bogor menuju Jakarta Kota dapat dikatakan cukup baik. Akan tetapi, PT KCI perlu menambahkan lebih banyak perjalanan rangkaian kereta atau dapat menambah jumlah gerbong dalam satu rangkaian untuk menghindari penumpukan penumpang terutama pada waktu sibuk yaitu pukul 04.00 WIB hingga pukul 08.00 WIB.

Penelitian ini masih terbatas pada perjalanan satu arah stasiun Bogor menuju stasiun Jakarta Kota. Oleh karena itu, pada penelitian selanjutnya disarankan untuk melakukan penelitian lanjutan dengan menambahkan kendala arus balik dengan distribusi penumpang berdasarkan periode waktu yang aktual.

\section{DAFTAR PUSTAKA}

[1] A.Y. Nurhidayat, H.Widyastuti, Sucipto, dan D.P.Utomo, "Model Of Transportation Mode Selection Between Private Vehicle and Serpong Tanah Abang Commuter Line," Advances in Engineering Research (AER), Vol. 147, Maret 2019.

[2] D. Gattuso dan A. Restuccia, "A Tool for Railway Transport Cost Evaluation," Procedia - Social and Behavioral Sciences, 111 ( 2014 ) 549-558, 2013.

[3] F. Dou, J. Xu, L. Wang, dan L. Jia, "A Train Dispatching Model Based on Fuzzy Passenger Demand Forecasting During Holidays," Journal of Industrial Engineering and Management, 2013-6(1):320-335,2013.

[4] F. Fischer, B. Grimm, T. Klug, dan T. Schlechte,"A Re-optimization Approach for Train Dispatching," Operations Research Proceedings Springer International Publishing AG 2018,645-651,2018.

[5] FA. Quinta dan E. Prakoso, "Kajian pemanfaatan moda transportasi kereta rel listrik (krl) commuter line dalam pergerakan komuter Bekasi-Jakarta," Jurnal Bumi Indonesia, Vol. 5, No. 2,2016.

[6] Jamaludin, R. Sadili, dan A. Alfisyahrin, "Analisis Perjalanan Kereta Rel Listrik pada Lintas Manggarai Bogor," Jurnal Perkeretaapian Indonesia, Vol. III No. 1,Maret 2019.

[7] Kementerian Perhubungan, "Peraturan Menteri Perhubungan Republik Indonesia No. 54 Tahun 2013 Tentang Rencana Umum Jaringan Angkut Massal Pada Kawasan Perkotaan Jakarta, Bogor, Depok, Tangerang, dan Bekasi (Jabodetabek)," 2013.

[8] L. Sijie, R. Xu, dan K. Han, "Demand-Oriented Train Services Optimization For A Congested Urban Rail Line: Integrating Short Turning and Heterogeneous Headways," Transportmerica A: Transport Sciences,.Print 23249943,Article doi: 10.1080/23249935.2019.1608475,2019. 
[9] L. Lamorgese, C. Mannino." The track formulation for the Train Dispatching problem," Electronic Notes in Discrete Mathematics,41(2013)559-566,2013.

[10] M. Lusiani dan S. Chandra, “Optimasi Jumlah Kedatangan KRL Commuter Line untuk Mengatasi Penumpukan Penumpang Jalur Bekasi - Jakarta Kota Menggunakan Simulasi Promodel," Journal of Industrial Engineering and Management Systems, Vol. 11, No. 1, 32-38,2018.

[11] PT KCI, "Sekilas PT Kereta Commuter Indonesia”, [Online]. Tersedia: http://krl.co.id/ [Diakses: 20 September 2019].

[12] WL Winston and JB Goldberg., "Operations research applications and algorithms”, California (US): Thomson Brooks/Cole, 2004.

[13] Y. Muhyi, "Pemodelan Penjadwalan Otomatis Sistem Kereta Rel Listrik (KRL) PT. KAI," Tesis Universitas Pembangunan Nasional Veteran,2010.

[14] Y. Yue, J. Han, S. Wang, dan X. Liu, "Integrated Train Time Tabling and Rolling Stock Scheduling Model Based on Time-Dependent Demand for Urban Rail Transit," Computer-Aided Civil and Infrastructure Engineering, 32(2017)856-873,2017.

[15] Y. Wang, A. D’ariano, J. Yin, L. Meng, T. Tang, dan B. Ning, "Passenger Demand Oriented Train Scheduling and Rolling Stock Circulation Planning for an Urban Rail Transit Line", Transportation Research Part B, 118 (2018) 193-227,2018 
